\title{
The worldview and values - analysing relations
}

\author{
MIROSŁAWA CZERNIAWSKA \\ Faculty of Engineering Management \\ Bialystok University of Technology \\ 45A Wiejska Street, Bialystok 15-351 \\ POLAND \\ JOANNA SZYDLO \\ Faculty of Engineering Management \\ Bialystok University of Technology \\ 45A Wiejska Street, Bialystok 15-351 \\ POLAND
}

\begin{abstract}
The described study serves as a basis for analysing relationships between two constructs: a worldview and values. In case of the former one, three types of worldview are considered: traditional, modern and postmodern (the Borowiak Questionnaire "How do you view yourself and the world around you?"). For the latter, the article refers to the Schwartz circular model of values: 19 values are located in two bipolar dimensions: conservation - openness to change and self-transcendence - self-enhancement (the Schwartz Portrait Value Questionnaire - PVQ-R3). Values were also classified into collective and individual types. The study involved 368 people. The aim was to find an answer to the question: which values are associated with the indicated worldviews? It appeared that collective values (the pole conservation and partially self-transcendence) were connected with the traditional worldview, individual values (the pole openness to change and partially selfenhancement and self-transcendence) - with modern and postmodern worldviews. The indicated regularities do not concern two individual values - "hedonism" and "achievement", where the correlations with the postmodern worldview were not statistically significant.
\end{abstract}

Key-Words: traditional, modern, post-modern worldview, values, the Schwartz model

Received: December 26, 2019. Revised: May 29, 2020. Accepted: June 3, 2020.

Published: June 4, 2020

Acknowledgment: The publication is financed from the resources for science of Ministry of Science and Higher Education of the Republic of Poland under subsidies granted to the Faculty of Engineering Management of the Bialystok University of Technology.

\section{Introduction}

The article presents the results of research that allow for describing the relation between the worldview and values. These constructs are in a way convergent: a worldview is a system of beliefs about the world, nature, man and his place in the world, connected with the system of values [1]. Values - as Rokeach [2] indicated - also are characterised by a status of beliefs. The author claimed that people prefer coherence between the beliefs they accept. In case of lack of cohesion, they feel an unpleasant state of tension, which motivates them to restore it. Taking into account Rokeach's assumption about the organization of beliefs within a system, the following research question was formulated: whether and to what values a particular type of worldview is associated. The worldviews covered by the analysis are formed on the basis of three cultural formations: traditionalism, modernism and postmodernism. Bauman considered them as great stages in Western culture [3-7]. The term "value" - according to Schwartz's concept adopted in the study [8-10]refers to many socio-cultural and psychological phenomena. For most people, values become permanent mental entities (abstract concepts) that have motivating properties and influence emotional states. The author supplemented and extended Rokeach's theory of values [2], maintaining the view that their analysis should take place in the context of a broader system of beliefs. 
Has the "worldview-value" relation been the subject of scientific research and how often? To answer this question, the authors reviewed articles in the Scopus database and applied bibliometric analysis. The analysis was carried out in three stages [11]:

Stage 1. Generating records in Scopus database:

- defining keywords,

- selection of search criteria,

- exporting the file.

Stage 2. Visualization of co-occurrence in the VOSviewer program:

- determination of the analysis parameters,

- cleaning the database from redundant phrases,

- generating a map based on bibliographic data.

Stage 3. Analysis of research findings:

- keywords analysis,

- indentification of research areas.

In the course of the analysis the number of articles was reduced down to 1,393 . The authors focused on such areas as: Business, Management and Accounting, Social Sciences, Psychology. A tool used in data ordering and presentation was VOSviewer programme. This software is particularly useful in working on extensive volume of data. It is a tool for creating and visualising bibliometric networks that use an advanced layout and clustering techniques in order to illustrate existing references between keywords characterising articles from scientific databases. The software draws attention to the frequency and co-existence of keywords that appear in the network [12-15]. In the second phase the authors determined such analysis parameters as a minimum number of keyword occurrences which equalled 5. As a result, the number of keywords to select from is 155. Cleaning the database from redundant phrases allowed for removing such repetitive words as names of countries and phrases that failed to be thematically coherent. This has fostered the mapping of research trends in value and worldview (Figure 1).

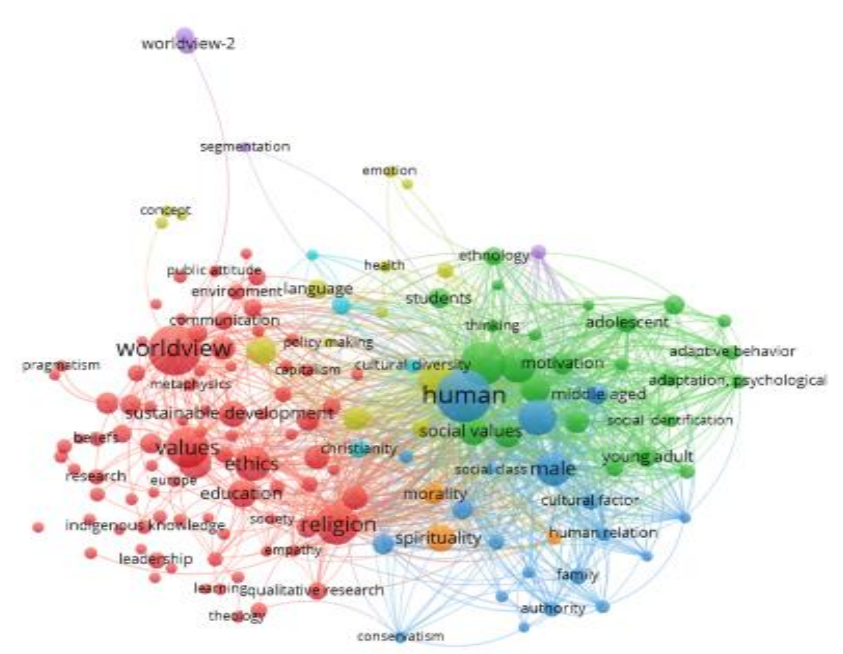

Figure 1. Map of research trends based on the cooccurrence of the authors' keywords in publications referring to values and worldviews

Source: author's elaboration on the basis of VOSviewer software.

VOSviewer software allowed for distinguishing seven clusters which in total included 153 words/phrases. The proposed cluster names refer to most terms identified by a given cluster in the analysis of the co-occurrence of indicated keywords (worldview and values). Clusters include such issues as:

- worldview relating to values, sustainable development, ethical, religious issues, education, ecology (cluster 1 contains 85 items and 77 publications);

- man and his thought processes, growing up (cluster 2 contains 24 items and 101 publications);

- man and his role in society, issues related to gender, relations, morality, role of authority, family, spirituality (cluster 3 contains 20 items and 110 publications);

- culture connected with a worldview, values, knowledge, religion, morality, language, gender, ethical issues (cluster 4 contains 14 items and 51 publications);

- research on worldviews (cluster 5 contains 4 items and 5 publications);

- scientific disciplines: history, psychology, philosophy, economics, ethnology (cluster 6 contains 3 items and 33 publications);

- spirituality related to a worldview, religion, morality, humanity, gender, ethics (cluster 7 contains 3 items and 54 publications).

It can be observed that literature on the relation "worldview - values" is rich and contains a description of numerous studies [16-26]. Nevertheless, no cluster provided for any publications that concern empirical verification of the 
relation between constructs: "traditional, modern, postmodern worldview" - "values" when these are considered from the point of view of the Schwartz 19element model [27]. Thus, the performed bibliometric analysis indicates a research gap in this area. It should also be stressed that there are relatively few studies based on Schwartz's 19-value model (using the Schwartz Portrait Value Questionnaire PVQ-R3). They relate, for example, to issues of attitudes [28], motivation [29-30], burnout [31], intergenerational differences in the axiological sphere [32]. The authors were also interested in the verification of this (i.e. 19-element) value model and methodological issues [33-34]. Only several studies were published in which the construct of traditional, modern and postmodern worldview was taken into account (using the Borowiak Questionnaire "How do you view yourself and the world around you?"). In the context of these worldviews, dating styles [35], relations in relations [36], political views [37], tolerance [38] and the so-called basic hope [39] were analysed.

\section{Traditional, modern postmodern worldview}

A worldview is identified, as indicated above, with an individual's system of beliefs with regard to the surrounding world as well as phenomena and processes taking place in it. According to Borowiak [4] - the author of the tool used in the described research - these are two types of beliefs: epistemological statements about the nature of truth and reality (e.g. "God is the truth", "God interferes in the temporal life of man", "God is an impersonal Logos, Nature identified with the laws governing the universe", "Truth is relative, it is always some kind of construction of the world that can be deconstructed, showing its limitations and conditions" [cf. 7]), and axiological claims about values that define the subject's own identity (e.g. "A good man is the one who lives honestly in the transcendental and temporal aspect", "The source (if not the essence) of evil, sin, misdeed is one's own ignorance, superstition, and maintaining others in such a conviction", "Evil is oppression in the form of subjecting people to the dictate of own truth" [cf. 7]). They form a complex cognitive metastructure. Borowiak analysed three great cultural stages (formations): traditionalism, modernism and postmodernism. Each of them created a dominant worldview (culture's distinguishing feature) which is used by people to constitute their identity, analyse life experiences, justify behaviour and explain events taking place in their world $[4,7]$. So what are their characteristics?

Traditionalism - as the name of the cultural trend suggests - focused on tradition, and especially on its religious aspect. It paid tribute to what was formerly established - timeless, supra-cultural and revealed truth. A moral man is the one who expresses his moral virtues, and thus unconditionally accepts and puts into practice commandments of faith and the social order approved by the Church. In modernism, the causative power was attributed to reason, which allows us to reach "one truth". The cult was surrounded not by religion, but by science (the wiser know better). Morality was identified with functioning in accordance with knowledge which refers to objective moral values. They were not revealed - as in traditionalism - but a mature person could discover them. The importance of man was considered in terms of the effectiveness of his actions: whether he was able to pursue rational, conscious and long-term goals so as to deserve fame among future generations. In postmodernism, the existence of objective truth (which was exposed in traditionalism and modernism) was questioned and replaced by the term "convention". Postmodernism was directed to irrationalism, cognitive and axiological relativism. The most important value became freedom and related individual autonomy. Man has the right to make an individual choice, seek novelty, change decisions and experience pleasure. It is the right of all people (universalism) and it can be expressed in their own way. However, they are obliged to tolerance and political correctness [40-45, 3-4, 7]. Man does not live to suffer, sacrifice himself (traditionalism) or postpone gratuities and constantly strive for success (modernism), but to be happy.

The three worldviews described above differ in chronology: their origins can be traced back to the Middle Ages, the Enlightenment and the 1950s. Nevertheless, they can be the source of epistemological and axiological beliefs (or fragments of them) of modern people. Their specificity (content) depends, among other things, on the role played in the life of individuals by religious and educational institutions, the media, popular culture and peer groups [46].

Boski, in characterising worldviews, linked them to values. He did so by imposing the cultural triad: traditionalism - modernism - postmodernism on the dimensions of values described by Schwartz [7]. The model under consideration allows for describing values at the level of cultural measurement and includes seven types [7]. The author indicated that the traditional worldview is close to the "conservatism" type value (social order, refraining 
from socially unacceptable impulses and actions, obedience, stability and protection of society, relationships with other people and oneself, respect for tradition, attachment to cultural customs and ideas), the modern worldview - "mastery" type values (ambition, boldness, skills disclosed in accordance with social standards), while the postmodern worldview is a type of "intellectual autonomy" (wide horizons, curiosity, independence of thought and action), "affective autonomy" (pleasure, exciting life, excitement, challenge, novelty, sensory gratification) and "egalitarian" (justice, equality, tolerance and protection of all people and nature) values. "Harmony" (sustaining and strengthening the well-being of the loved ones) and "hierarchy" (power, control over people and resources) were not associated with any worldview. The analysis of the relationship was carried out by Boski at the theoretical level and has not yet been empirically verified.

This paper presents an assumption that there is a close relation between a particular worldview (vision of the world) and values on the basis of subject research. However, it was verified against another (modified in 2012), Schwartz model.

\section{The Schwartz circular value model}

The modified Schwartz model contains 19 types of values that are inscribed in the continuum [ cf. 47]. It includes measurement of values at an individual level. Table 1 presents poles of dimensions at which the values, value types and their definitions are located. Additionally, it includes the division of values into individual and collective. The brackets provide types of values which are operated in the $7-$ element cultural model [cf. 7].

Table 1. The Schwartz model: 19 types of values, their location on dimensions: conservation - openness to change and self-enhancement - self-transcendence.

Division into individual and collective values

\begin{tabular}{|c|c|c|c|c|}
\hline$\frac{\mathscr{E}}{\tilde{J}}$ & 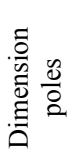 & No. & Type of value & $\begin{array}{c}\text { Characteristics of } \\
\text { value types }\end{array}$ \\
\hline $\begin{array}{l}\vec{\sigma} \\
\vec{z} \\
\sigma \\
\vec{z} \\
\vec{z}\end{array}$ & \multirow{2}{*}{ 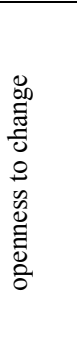 } & 1 & $\begin{array}{l}\text { self-direction- } \\
\text { thought } \\
\text { (intellectual } \\
\text { autonomy) }\end{array}$ & $\begin{array}{l}\text { autonomy in } \\
\text { thinking; freedom in } \\
\text { seeking and selecting } \\
\text { own ideas as well as } \\
\text { developing one's } \\
\text { skills; shaping one's } \\
\text { own worldview }\end{array}$ \\
\hline $\begin{array}{l}\tau \\
= \\
=\end{array}$ & & 2 & $\begin{array}{l}\text { self-direction- } \\
\text { action } \\
\text { (intellectual } \\
\text { autonomy) }\end{array}$ & $\begin{array}{l}\text { autonomy in making } \\
\text { decisions and } \\
\text { executing one's own }\end{array}$ \\
\hline
\end{tabular}

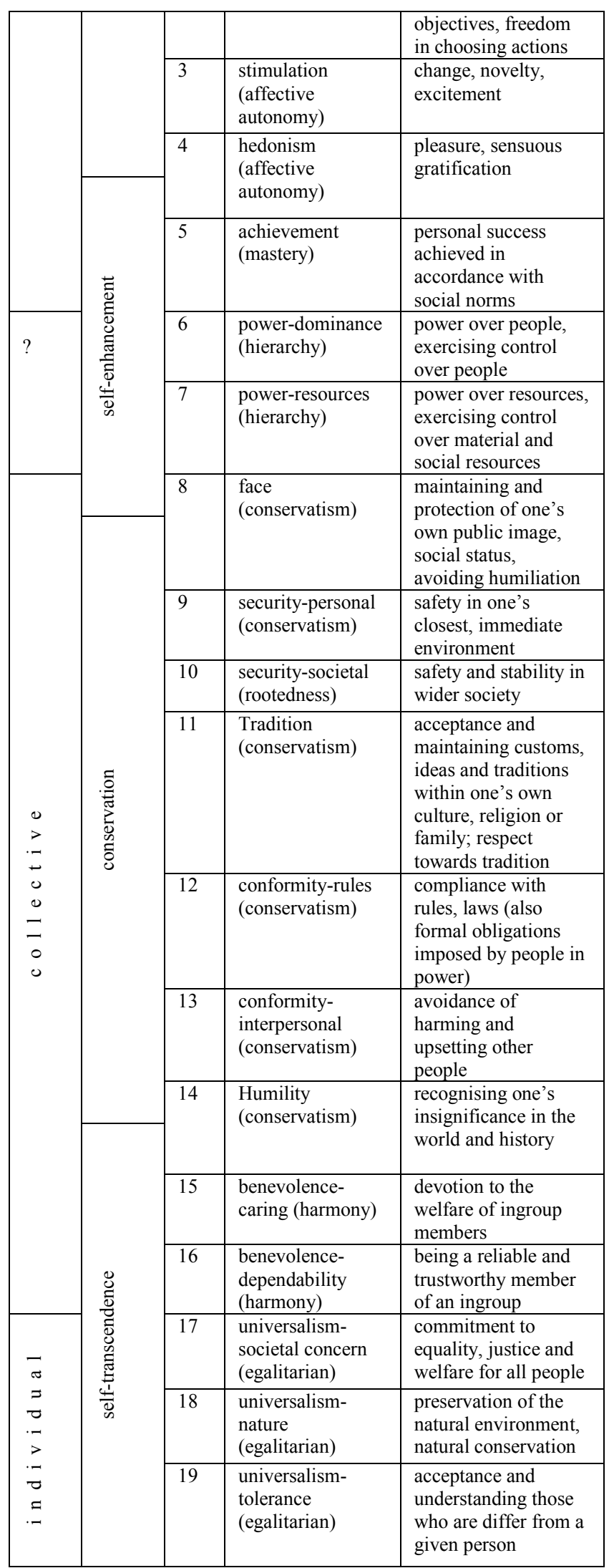

Source: elaboration on the basis of [47].

Schwartz indicated that the above described values can be located in two bipolar dimensions:

- conservation - openness to change; 
- self-enhancement - self-transcendence.

The first of these dimensions reflects a conflict between the pursuit of stability and the cultivation of traditions as well as the pursuit of change and a high value of autonomy, manifested in independence of thinking and conduct. The second dimension reflects a conflict between self-concentration and concentration on others. Self-concentration is related to self-promotion, the pursuit of domination and the orientation of activity towards personal success. Focusing on others requires abandoning the egocentric perspective, taking into account the wellbeing of the other person and promoting their welfare [48].Types of values 1-4 belong to the pole of openness to change (with the last value belonging partly to the self-enhancement pole), types of values 5-7 in turn - to the self-enhancement pole. Types of values $8-14$ belong to the conservation pole (with the first and last value partly belonging to the selfenhancement or self-transcendence pole), while types of values 15-19 - to the self-transcendence pole (cf. Table 1). Values which are adjacent to each other (or are at a short distance) are positively correlated (e.g. "tradition", "conformity-rules", "conformityinterpersonal"); values which are located on the opposite side of the circle (in relation to the centre) correlate negatively. In the first case, the values trigger compatible motivations, in the second case mutually exclusive motivations (more on this subject in: [49, 27]). For example, behaviours aimed at protecting customs, cultural heritage and traditions (stimulated by the value "tradition") contribute to the initiation of conformist conduct (stimulated, among other things, by the value "conformity"). The values of "tradition" and "conformity" guide the aptitude to meet external expectations and the attention paid to own group. However, this can be "wrecked" by the pursuit of novelty and change. This behaviour is initiated by the opposing value "stimulation". Hence, it becomes necessary to compromise values that promote and inhibit a given behaviour.

The classification of values can be carried out with reference to a more general construct, which is individualism - collectivism. Generally speaking, the distinction is made according to the criterion: selfconcentration and concentration on the group to which the individual belongs. In the first case, values are related to the freedom of choice, independence of thought and action, personal success (achievement), performance, autonomy, intellectual competence, need for stimulation and hedonism, in the second case - to the protection of other people, the good of the community, respect for the elderly, recognition of tradition (religion), maintenance of social order, balanced views, security as well as interpersonal and intrapersonal harmony [50-52, 48, 53-59].

Taking into account the Schwartz model presented above, it should be concluded that individual values are those that form part of the pole openness to change (1-4), collective values are those that form part of the pole conservatism (8-14). The pole self-transcendence includes both individual and collective values. Values associated with universalism (17-18) are individualistic. They refer to the equality of all people and disregard the issue of group affiliation (which is important in collectivism). Values related to benevolence (15-16), in turn, are of a collective nature and refer to relationships among closely related people. The pole self-enhancement contains an individual value of "achievement" (5). It also contains values related to power (6-7). They refer to issues related to the acceptance of social hierarchy and material diversity (cf. Table 1). Triandis and Gelfand [60] drew attention to the fact that both individualism and collectivism can have a vertical form, stigmatised by inequality. They were contrasted against individualism and horizontal collectivism, which emphasise equality and disapprove of values associated with power. In the light of such considerations it is difficult to classify "power-dominance" and "power-resources" as collective or individual values. On the other hand, if the value "universalism" is considered individual, then "power" - located on the opposite side of the circle - should be considered collective. This is in line with the assumptions made in the Schwartz circular model.

The Schwartz model has undergone several modifications, but the understanding of values has not changed. They are identified with a central and stable conviction. Values constitute desirable, crosssituational goals that vary in importance. They serve as guidelines in the life of a given person or group and are considered as standards of conduct. Values shape positions on social issues, predispose people to favour ideologies and constitute a basis for formulating evaluations of oneself and other people as well as justifying behaviour [61, 8-10, 63]. Values are a construct that combines cultural influences with internal development. A person integrates information about values in a way that is specific to $\mathrm{him} / \mathrm{her}$ (for example, in the context of individual characteristics, personal life experiences, social roles) and defines their meaning. It does not have to reflect in its psychological dimension the whole characteristics of culture, but there is a greater similarity in the understanding of values and construction of individual axiologies among people belonging to the same cultural circle. This remark 
also applies to the environment promoting particular types of worldviews.

\section{Research problem and hypotheses}

Worldviews (visions of the world) imply a certain type of values [7,63]. These two constructs should be interrelated due to the fact that they are beliefs containing - at least to some extent - convergent content. People seek a structural organisation of beliefs (although this organisation varies from person to person depending on the development of cognitive structures), and the resulting consistency has an important regulatory function. It allows for creating a coherent vision of the world and determines human behaviour in a relatively constant manner. Beliefs constitute a unique kind of tool that helps to understand reality: they are used to formulate views about what the world is and what it should be [64]. Through them, human mind constitutes general knowledge about this world. However, different beliefs are assigned with different meanings. Rokeach [2] claims that values play the most important role and represent the highest level of beliefs. According to this author, the system of beliefs is not only consistent (as noted above), but also hierarchically organised. The presented assumptions refer to the theory of cognitive conformity, according to which people prefer consistency between accepted beliefs (cf., e.g., theories of Heider, Newcomb, Osgood and Tannenbaum, Festinger or Rosenberg) [48]. In the absence of consistency, however, they feel an unpleasant state of tension that motivates them to restore it.

The research described in this article is focused on the relation between the worldview - traditional, modern and postmodern - and values. Modes of interpretation of these constructs are discussed in the theoretical part of the paper. It is assumed that each of the three worldviews has its axiological specificity. In empirical terms, this means that the indicators of each worldview are related to the indicators of values "inscribed" in this worldview on the basis of content-based compliance.

Taking into account definitions of value types and their classifications presented in the theoretical part of the article, the following relations are assumed:

Hypothesis 1: The traditional worldview is associated with collective values located at the poles:

- conservation: "face", "security-personal", "security-societal", "tradition", "conformity-rules", "conformity-interpersonal" and "humility";

$$
\text { self-transcendence: "benevolence- }
$$

dependability" and "benevolence- caring".
Hypothesis 2: The modern and postmodern worldviews are associated with individual values located oat the poles:

- openness to change: "self-direction-thought", "self-direction-action", "stimulation" and "hedonism";

- self-enhancement: "achievement";

- self-transcendence: "universalism-societal concern", "universalism-nature" and "universalismtolerance".

Both the cultural trend of modernism and postmodernism "encourage" people to shape such an axiology in which relatively high importance is attached to individual values. They do not necessarily have to be the same values. Boski [7] draws attention to two types of individualism: based on achievements and on autonomy. The former - with its flagship value "achievement" - lies at the heart of the modern worldview, while the latter - described by the values "self-direction-thought", "self-direction-action", "stimulation" and "hedonism" - forms the core of the postmodern worldview. This research was focused on verifying whether this is the actual case. It disregards the hypotheses of values "powerdominance" and "power-resources" due to their undefined status (cf. elaborations in the theoretical part of the paper).

\section{Method}

The survey involved 368 Polish students, out of whom women constituted $80 \%$. The age of respondents oscillated between $20-24$ years.

The study incorporated the Borowiak Questionnaire "How do you view yourself and the world around you?", on the basis of which the indicators of three worldviews were obtained for each person surveyed: traditional, modern and postmodern. Each worldview is juxtaposed by 12 statements. It was necessary to address them on a 7 -grade scale. The indicators range from 12 to 84 [7].

The Schwartz Portrait Value Questionnaire (PVQR3) consists of 57 statements (items). The respondent is to determine (on a scale of 1-6) the extent to which he or she is similar to the person characterised in each statement. Based on these 57 estimates, indicators of 19 value types are determined. The average obtained from three items constitutes an indicator of preference for a given type of value. The average of all (i.e. 57) items must be subtracted from the average obtained for each value type. In this manner an indicator of each of 19 value types for each person surveyed is obtained. The consequence of this procedure is the negative result of some indicators [47]. 


\section{Results}

The aim of the study was to empirically verify the relation: worldview - values. Table 2 presents averaged indicators of variables and the results of statistical analysis.

Table 2. Worldview - traditional, modern and postmodern - versus values: analysis of relations

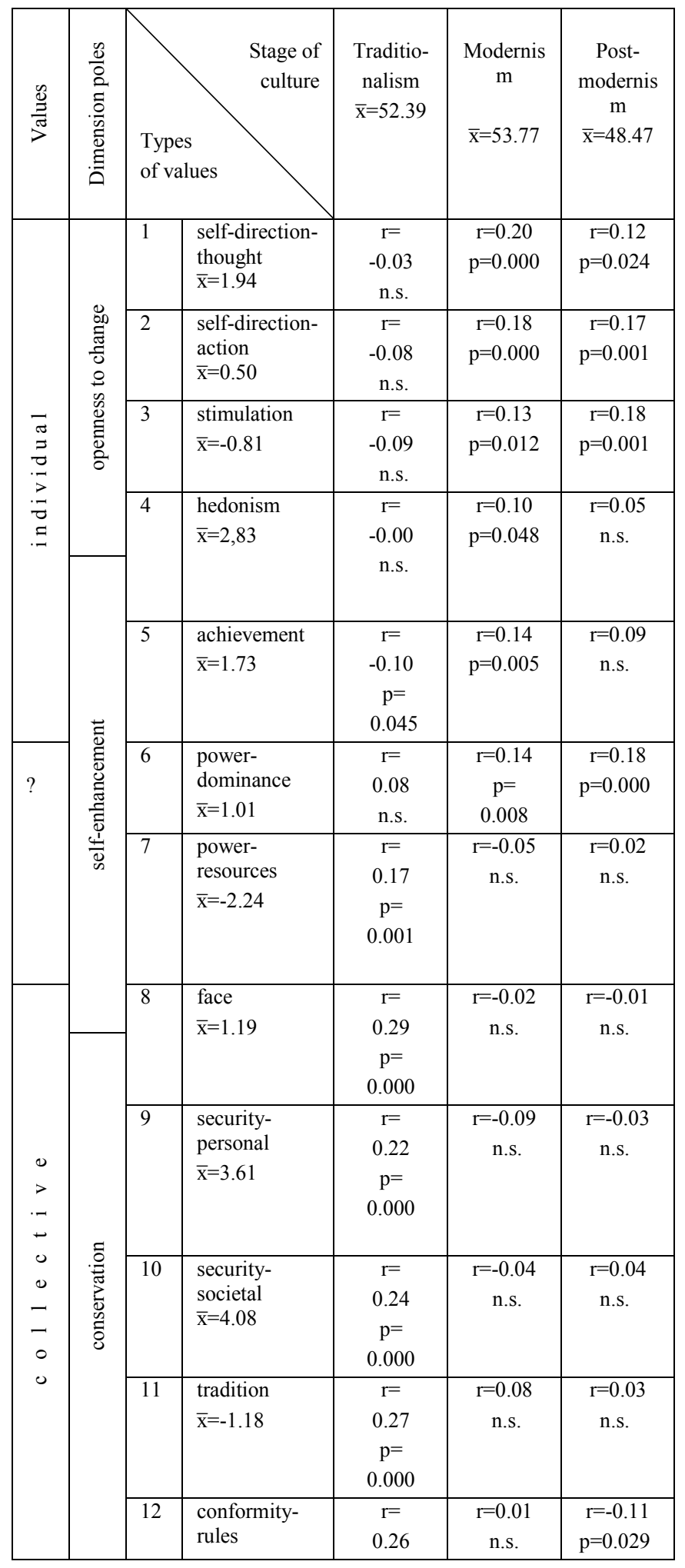

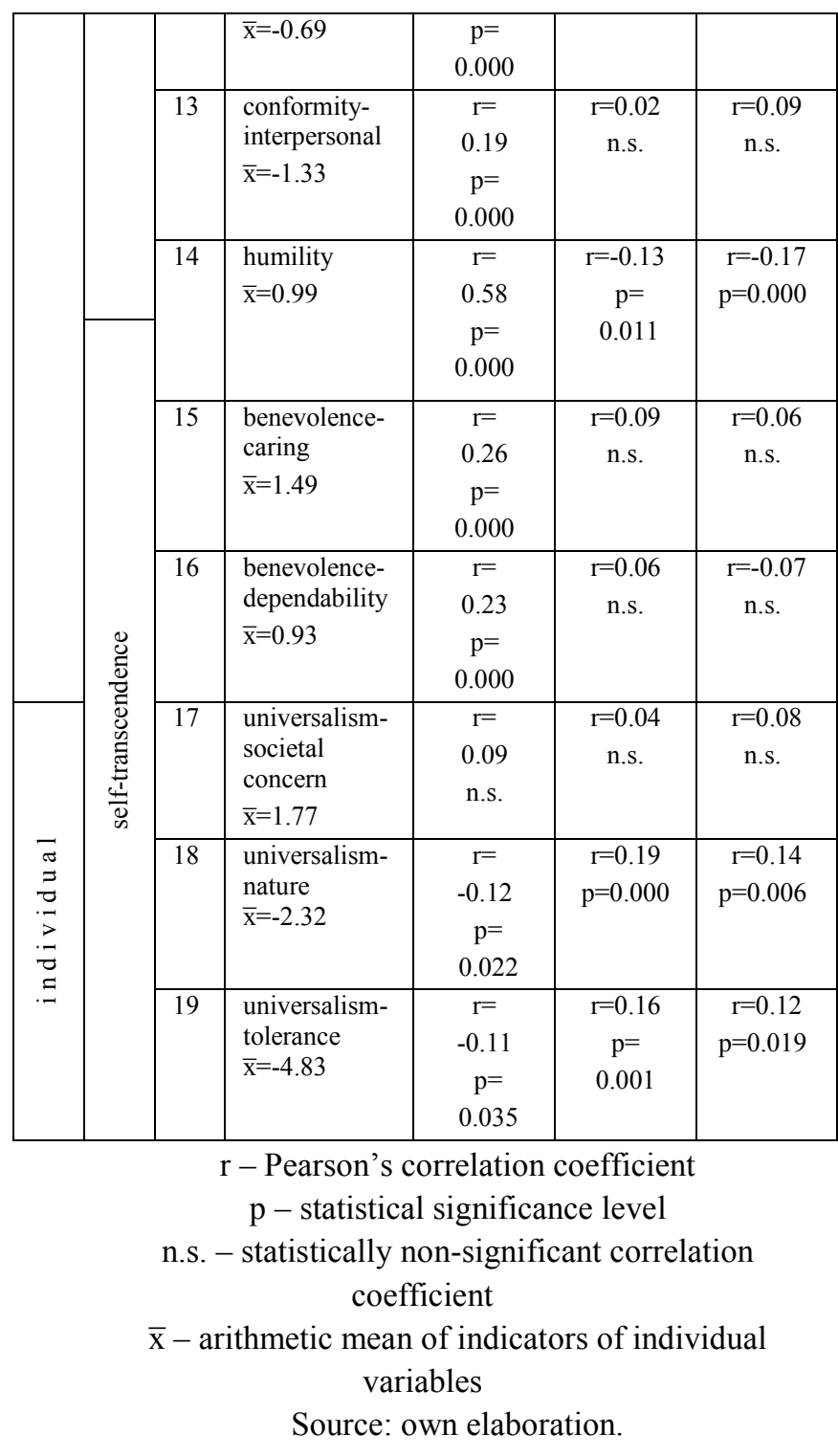

In the light of the obtained results, it should be stated that the traditional worldview is correlated with collective values (cf. Table 2, Fig. 2). Positive and statistically significant coefficients of correlation with the values at the pole are observed: - conservation (8-14), i.e., "face" $(r=0.29$; $p=0.000)$, "security-personal" $(\mathrm{r}=0.22 ; \mathrm{p}=0.000)$, "securitysocietal" $(\mathrm{r}=0,24 ; \mathrm{p}=0,000)$, "tradition" $(\mathrm{r}=0.27$; $\mathrm{p}=0.000)$, "conformity-rules" $(\mathrm{r}=0.26 ; \mathrm{p}=0.000)$, "conformity-interpersonal" $(\mathrm{r}=0.19 ; \mathrm{p}=0.000$, and "humility" $\quad(\mathrm{r}=0.58 ; \quad \mathrm{p}=0.000) \quad(8-14)$; - self-transcendence (15-16), i.e. "benevolencecaring" $(\mathrm{r}=0.26 ; \quad \mathrm{p}=0.000)$ and "benevolencedependability" $(\mathrm{r}=0.23 ; \mathrm{p}=0.000)$.

The obtained results confirm the assumptions formulated in hypothesis 1. Negative correlation coefficients with values "achievement" (a part of the self-enhancement pole $)(\mathrm{r}=-0.10 ; \mathrm{p}=0.045)$ and "universalism-nature" $\quad(\mathrm{r}=-0.12 ; \quad \mathrm{p}=0.022) \quad$ and "universalism-tolerance" $(\mathrm{r}=-0.11 ; \mathrm{p}=0.035)$ (a part 
of the self-transcendence pole) are observed in case of this worldview. Such dependencies were not included in the hypotheses, but they are consistent with the Schwartz model (cf. theoretical part of the paper).

The modern worldview is associated with individual values (cf. Table 2, Fig. 2). Thus, positive and statistically significant correlation coefficients with the values at the pole are observed:

- openness to change (1-4), i.e. "self-directionthought" $(\mathrm{r}=0.20 ; \mathrm{p}=0.000)$, "self-direction-action" $(\mathrm{r}=0.18 ; \mathrm{p}=0.000)$, "stimulation" $(\mathrm{r}=0.13 ; \mathrm{p}=0.012)$ and "hedonism" ( $\mathrm{r}=0.10 ; \mathrm{p}=0.048)$;

- self-enhancement (5), i.e. "achievement" $(\mathrm{r}=0.14 ; \mathrm{p}=0.005)$;

- self-transcendence (18-19), i.e. "universalismnature" $\quad(\mathrm{r}=0.19 ; \mathrm{p}=0.000)$ and "universalismtolerance" $(\mathrm{r}=0.16 ; \mathrm{p}=0.001)$.

The obtained results confirm hypothesis 2 . It should be stressed that the modern worldview correlated positively with the value "achievement". It plays a special role in it, as indicated in the theoretical part of the article. Negative correlation coefficients between modernism and the collective value "humility" are also noted ( $\mathrm{r}=-0.13 ; \mathrm{p}=0.011)$. This correlation was not included in the hypothesis, but is consistent with the Schwartz model (cf. theoretical part of the paper).

The postmodern worldview - as assumed (hypothesis 2) - is associated with individual values (Table 2, Fig. 2). Positive and statistically significant correlation coefficients with the values at the pole are observed:

- openness to change (1-3), i.e. "self-directionthought" $(\mathrm{r}=0.12 ; \mathrm{p}=0.024)$, "self-direction-action" $(\mathrm{r}=0.17 ; \mathrm{p}=0.001)$, "stimulation" $(\mathrm{r}=0.18 ; \mathrm{p}=0.001)$;

- self-transcendence (18-19), i.e. "universalismnature" $(\mathrm{r}=0.14 ; \mathrm{p}=0.006)$ and "universalismtolerance" $(\mathrm{r}=0.12 ; \mathrm{p}=0.019)$.

The number of correlating values is lower than in the case of the modern worldview. In comparing both worldviews, the lack of statistically significant correlation coefficients with the values of "hedonism" and "achievement" should be noted (in Fig. 2 they are marked in grey). As indicated, "achievement" is an indicator of modernism. However, the significance of this value in postmodernism is not indicated (and it was even discarded). However, "hedonism" - reflecting the pursuit of affective autonomy, pleasure and exciting life - constitutes a pillar of postmodernism. Therefore, the obtained result does not reflect the idea of this worldview. On the other hand, negative correlation coefficients with collective values of "humility" ( $\mathrm{r}=-0.17 ; \mathrm{p}=0.000)$ and "conformity- rules" $(\mathrm{r}=-0.11 ; \mathrm{p}=0.029)$ are consistent with the ideology of postmodernism (these correlations were not included in the hypothesis). They also fit into the Schwartz value model since they are in opposition to autonomy (cf. theoretical part of the paper).

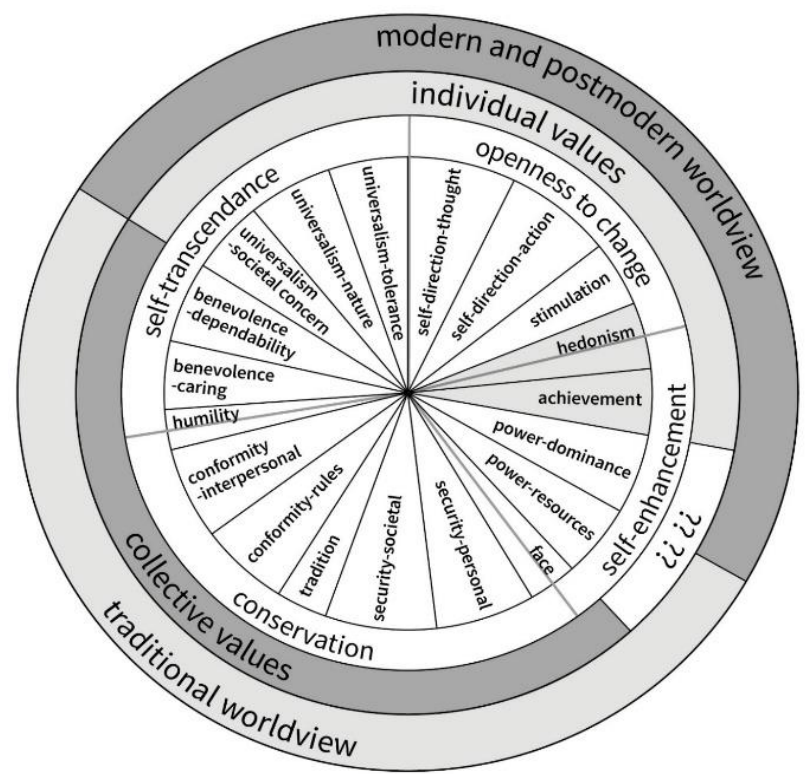

Figure 2. Relations between the traditional, modern and postmodern worldview with values

- $\quad$ the Schwartz model was incorporated: 19 value types are located in two dimensions: conservation - openness to change and selfenhancement - self-transcendence;

- $\quad$ values are divided into collective and individual;

- values "hedonism" and "achievement" marked in grey - do not correlate with the postmodern worldview

- positive correlation coefficients are diagnosed between the worldview and values located within its frames Source: own elaboration.

Finally, the analysis covers two values which raised doubts towards their classification (cf. Tables 1 and 2 and Fig. 2): collective versus individualistic. It appears that "power-resources" (7) is positively correlated with the traditional worldview $(\mathrm{r}=0.17$; $\mathrm{p}=0.000$ ) (i.e. the one in which positive correlations with collective values emerged), "power-dominance" (6) - with the modern $(\mathrm{r}=0.14 ; \mathrm{p}=0.008)$ and $(\mathrm{r}=0.18$; $\mathrm{p}=0.000$ ) postmodern worldviews (i.e. the ones in which positive correlations with individual values were revealed). The obtained results encourage interpretation from the point of view of the Schwartz model, which is presented in the following part of the paper. 


\section{Discussion and conclusion}

In the described study the authors made an analysis of the relation between worldviews traditional, modern and postmodern - and a system of values. These constructs originate from various theoretical concepts. However, the interest was focused on whether and to what extent they are convergent. The values were considered from the point of view of the Schwartz 19-element model, in which they are located in two dimensions: conservation - openness to change, self-enhancement - self-transcendence. They were also classified according to a more general criterion, i.e. individualism - collectivism. The authors expected a relation between the worldview and values to be based on the principle of content-based compliance. It was assumed that collective values would be positively correlated with the traditional worldview, while individual values would be correlated with modern and postmodern worldviews. It was also allowed (which was not included in hypotheses) that not all individual values would have analogous relations with modern and postmodern worldviews. This is due to the fact that they stimulate various types of motivation. It may be the pursuit of achievements - which is associated primarily with modernism, but also the pursuit of intellectual and affective autonomy - which is associated primarily with postmodernism. Is this way of thinking confirmed in the obtained results and does it allow for confirming research hypotheses?

A vast majority of assumptions is positively verified. It appeared that the traditional worldview is associated with collective values, which are part of the conservation pole: "face", "security-personal", "security-societal", "conformity-rules", "conformity-interpersonal", "tradition" and "humility". The highest correlation coefficient was obtained in the case of the value "humility" $(\mathrm{r}=0.58$, cf. Table 2), which is undoubtedly crucial in describing the traditional worldview. In Christianity, it is identified with a moral virtue - or even with the foundation of other virtues - the humbleness of the human spirit before God, the recognition of one's imperfections and sins. The modern worldview was associated with all individual values that are part of the pole openness to change: "self-directionthought", "self-direction-actions", "stimulation" and "hedonism". The same was true of the postmodern worldview. The exception was the value of "hedonism" (interestingly, considered as the "essence" of postmodernism), where the correlation coefficient was statistically insignificant. It should be noted that in the analysis of the relation between the three worldviews and the types of values belonging to the dimension of conservation - openness to change, it is the only case that is inconsistent with the hypotheses.

The values indicated above - "self-directionthought", "self-direction-action", "stimulation" and "hedonism" - are connected with a specific identity, i.e. personal identity. Here, man perceives himself as a unique being, which manifests itself in a tendency to think in terms of "I". Social identity, in turn, refers to the recognition of one's own person as belonging to a group, where a tendency to think in terms of "We" is characteristic. Then the values that foster unity with other people, stability and amicability (i.e. those that are part of the pole of conservatism) gain importance. These both forms of identity are shaped through different psychological processes: individuation (distinction, separation, differentiation) and identification (likenesses, identification, reconciliation). The former moulds personal identity, and the latter - social identity. Although both forms of identity emerge in all people, they may differ in terms of clarity and play an unequal role in the regulatory system [65-68]. The predominance of a given form of identity is largely determined by social factors. People with different cultural experiences differ in the degree of their education and ease of revision.

What kind of relations emerged in the context of the second dimension of values, i.e. selftranscendence - self-enhancement? The selftranscendence pole consists of both collective and individual values. The former - "benevolencecaring" and "benevolence-dependability" - were connected with the traditional worldview, the latter "universalism-nature" and "universalism-tolerance" - with the modern and postmodern worldview. These are results consistent from the theoretical point of view. The sense of "benevolence" and "universalism" is manifested in the fact that an individual is willing to leave an egocentric perspective and strive for the welfare of others. Nevertheless, "benevolence" is above all provided with a high rank by collectivists who seek to become rooted in their own group, identify themselves with it and ensure positive contacts and harmony in close relationships. As Schwartz [61] points out, it is reflected in the concern for the welfare of other people with whom the subject interacts on a daily basis (thus important in closed relationships). "Universalism", on the other hand, gives rise to the pursuit of equal treatment of people - regardless of their group affiliation (also those who belong to foreign groups) - understanding, tolerance and concern for the good of every human being. "Universalism" manifests itself in its concern to 
establish social justice. This value is closer to individualists who function in a broader social context than their own group and more often engage in behaviour aimed at building positive relations with the members of foreign groups.

The types of values that make up the selfenhancement pole are also partially individual, partially collective. The individual type of value "achievement" is understood as personal success. It was associated only and exclusively with the modern worldview. This dependence is in line with the ideology of this cultural trend and even reflects its essence: the measure of human value is the great deeds that ensure fame in the next generations. In case of this individual value there is no connection with postmodernism.

No hypothesis has been formulated regarding two values - "power-resources" and "power-dominance". The difference between them concerns the object of control: these may be material and social resources or people. As it turned out, the former is correlated with the traditional worldview, the latter with the modern and postmodern worldview. Hence, does the former "fit" more to collective values, which are the pillar of traditionalism, while the latter to individual values, which constitute the pillar of modernism and postmodernism?

According to the Schwartz circular model, the neighbouring values are positively correlated and trigger compatible motivations (cf. theoretical part of the paper). The values "power-resources" and "face" have such a location. Motivations can also be considered compatible, as gaining prestige is conditioned (at least to some extent) by control over material and social resources. Moreover, gaining control over resources enables the realisation of a typically collective value, which is "security". On the other hand, it should be noted that the pursuit of such resources does not fully fit into the traditional worldview. In Christianity, humble poverty was a virtue - "it is easier for a camel to pass through the ear of a needle than for a rich man to enter the Kingdom of Heaven". This problem was interpreted differently in the so-called Protestant work ethic. The value "power-dominance" is located in the vicinity of the value "achievement". There is a relation between them since there is a high likelihood of achievements if people are controlled (and often treated instrumentally). However, these considerations apply only to the modern worldview. In postmodernism, achievements are no longer attributed with any key importance (as confirmed by this study). What is surprising, then, is its overwhelming relation to the value "power-dominance" since it glorifies autonomy and unrestricted freedom.
There are also negative correlation coefficients with some values. It appeared that the higher the indicators of the traditional worldview, the lower the acceptance of individual types of values: "achievement", "universalism-nature" and "universalism-tolerance". It was also observed that the higher the indicators of the modern worldview, the lower the acceptance of the value "humility", and, the higher the indicators of the postmodern worldview, the lower the acceptance of the value "humility" and "conformity-rules". The obtained results correspond with the Schwartz model, as the value types located on the opposite side of the circle reflect opposite aspirations (opposition motivations). It is not surprising, for example, that people with a traditional worldview do not focus too much on personal success, while humility and the pursuit of scrupulous observance of rules is relatively alien to people with a postmodern worldview.

Generalising the obtained research results and placing them in the Schwartz model, it should be noted that the pool of ten adjacent values is connected with the traditional worldview, the pool of eight adjacent values - with the modern worldview, and pool of six values (apart from the values "achievement" and "hedonism") - with the postmodern worldview. The borderline values are: "power-resources" and "power-dominance" (selfenhancement pole) on the one hand, and "benevolence-dependability" and "universalismnature" (self-transcendence pole) - on the other hand (the in-between value of "universalism-societal concern" did not correlate with any worldview). Axiological differences based on the criterion of collectivism - individualism are revealed in the juxtaposition: traditional worldview - modern and postmodern worldview (cf. Fig. 1). It cannot be ignored that the last two worldviews correlate in the vast majority with the same values. Why are there such small axiological differences between them is postmodernism is a contestation of modernism? It should be stressed that worldviews differ not only in the content of the values associated with them, but also in the beliefs about their ontological status. Are these values absolute and do they exist objectively? Is it possible to present their only "right" hierarchy? Traditionalists and modernists - despite numerous differences in the content aspect of value systems believe so, and postmodernists - to the contrary. The latter negated the existence of "one truth" - also axiological. It depends on time, place and a person who interprets it. Human freedom manifests itself in that man can construct his own axiology and change it in the light of life experiences. It also becomes more difficult to assess in a value-based way, as 
everything is relative, borderless and undefined. And there is no reason for it to happen otherwise. Social order does not have to - as in traditionalism or modernism - be based on a common axiology.

Finally, methodological remarks which refer to the Schwartz value model will follow. The first publications with this regard appeared in the 1980s and referred to the Rokeach theory [51]. The author modified the model several times and distinguished a different number of value types. The result of his work was, among other things, the so-called cultural map of the world [69] and showing axiological specificity of societies living in different countries and on different continents, based on the developed measurement of values. The last 19-element Schwartz model (used in this study) differs from the previous ones not only in the number of value types, but also in the way they are measured. The Portrait Value Questionnaire (PVQ-R3) did not cover abstract value concepts, but presented the characteristics of a person and asked for determining the degree of similarity to him/her. As it turned out, the adopted theoretical model and the way of measuring values allowed for the axiological characteristics of the three worldviews. As indicated above, they are related to the three great stages of Western culture. Culture in this case is considered not in the geographical dimension (as Schwartz maintained in the course of his long-term research), but in the historical dimension, as Bauman did [42].

\section{References:}

[1] Cieciuch, J. Czym jest światopogląd? Filozoficzny kontekst psychologicznego pojęcia, Psychologia Rozwojowa, 10(2), 2005, pp. 147-159.

[2] Rokeach, M, The nature of human values, Free Press, New York 1973.

[3] Borowiak, A. O czym mówimy, kiedy dyskutujemy o dyskursie postmodernistycznym?, In: Psychologiczne studia nad językiem i dyskursem, I. Kurcz, J. Bobryk (ed.), Wydawnictwo Instytutu Psychologii PAN i Wydawnictwo SWPS Academica, Warszawa 2001, pp. 141-175.

[4] Borowiak, A. Światopogląd postmodernistyczny a postulat tolerancji, In: Tolerancja $i$ wielokulturowość. Wyzwania XXI wieku, A. Borowiak, P. Szarota (ed.), Wydawnictwo SWPS Academica, Warszawa 2004.

[5] Borowiak, A. \& Golec, A. Poznawcze i światopoglądowe wyznaczniki preferencji politycznych, Studia Psychologiczne, 42 (2), 2004, pp. 5-16.

[6] Borowiak, A. \& Szarota P. Światopogląd partnerów jako modulator miłości, Studia Psychologiczne, 42(3), 2004, pp. 15-26.

[7] Boski, P. Kulturowe ramy zachowań społecznych. Podręcznik psychologii międzykulturowej, Wydawnictwo Naukowe PWN, Wydawnictwo SWPS Academica, Warszawa 2009.

[8] Schwartz, S.H. Are there universal aspects in the structure and contents of human values? Journal of Social Issues, 50(4), 1994, pp.19-45.

[9] Schwartz, S.H. Value priorities and behavior: Applying a theory of integrated value systems, In: The psychology of values: The Ontario Symposium, C. Seligman, J.M. Olson, M.P. Zanna (ed.), Lawrence Erlbaum Associates, Inc, Mahwah, New Jersey, Vol. 8, 1996, pp. 1-24.

[10] Schwartz, S.H. Wartości, In: Encyklopedia Blackwella. Psychologia społeczna, A.S.R. Manstead, M. Hewstone (ed.), Wydawnictwo Jacek Santorski \& CO, Warszawa 1996.

[11] Cichowicz, E. \& Rollnik-Sadowska, E. Inclusive growth in CEE countries as a determinant of sustainable development, Sustainability, Vol. 10, No. 11, 2018.

[12] Gudanowska, A.E. Modern research trends within technology management in the light of selected publications, Procedia Engineering, Vol. 182, 2017, pp. 247-254.

[13] Glińska, E. \& Siemieniako, D. Binge drinking in relation to services - bibliometric analysis of scientific research directions, Engineering Management in Production and Services, 10(1), 2018, pp. 45-54.

[14] Siderska, J. \& Jadaa, K.S. Cloud manufacturing: a service-oriented manufacturing paradigm. A review paper, Engineering Management in Production and Services, 10(1), 2018, pp. 22-31.

[15] Winkowska, J., Szpilko, D. \& Pejić, S. Smart city concept in the light of the literature review, Engineering Management in Production and Services, 11(2), 2019, pp. 70-86.

[16] Brandt, M.J. \& Crawford, J.T. Worldview conflict and prejudice, Advances in Experimental Social Psychology, Vol. 61, 2020, pp. 1-66.

[17] Khlyscheva, E.V., Dryagalov, V.S., Topchiev, M.S., Romanova, A.P. \& Bicharova, M.M. 
Postmodern rhizome and models of religious identity, European Journal of Science and Theology, Vol. 16, Issue 1, 2020, pp. 119-130.

[18] Hakio, K. \& Mattelmäki, T. Future skills of design for sustainability: An awareness-based cocreation approach, Sustainability, Vol. 11, Issue 19, 2019.

[19] Komarova, A.A. Comparative analysis of the level of formation of the informational worldview of students of the pedagogical university of various fields of education, Perspektivy Nauki i Obrazovania Vol. 39, Issue 3, 2019, pp. 142-160.

[20] Alontseva, N.V, Ermoshin, Y.A., Dugalich, N.M., Kupriyanova, M.E. \& Dmitrieva, E.G. Worldview orientations of religious literature as an agent of socialization in the modern society, European Journal of Science and Theology, Vol. 15, Issue 3, 2019, pp. 157-166.

[21] Kushkimbayeva, A., Dyussembina, G., Tutinova, N. \& Khalimullina, N. The concept of people's cognitive model as a national and cultural worldview, Opcion, Vol. 35, Special Issue 22, 2019, pp. 440-453.

[22] Zanocco, C.M. \& Jones, M.D. Cultural Worldviews and Political Process Preferences, Social Science Quarterly, Vol. 99, Issue 4, 2018, pp. 13771389.

[23] Bawden, R. \& Allenby, B. Sustainability science and the epistemic challenge: some matters philosophical and why we ought to come to know them better, Sustainability Science, Vol. 12, Issue 6, 2017, pp. 901-905.

[24] Nilsson, A. Humanistic and normativistic worldviews: Distinct and hierarchically structured, Personality and Individual Differences, Vol. 64, 2014, pp. 135-140.

[25] Gratani, M., Sutton, S., Butler, J.R., Bohensky, E.L. \& Foale, S. Indigenous environmental values as human values, Cogent Social Sciences, Vol. 2, Issue $1,2016$.

[26] Magee, R.G. Worldview beliefs, morality beliefs and decision-making referents: Implications for the psychology of morality and ethics instruction, Advances in Psychology Research, Vol. 100, 2014, pp. 1-24.

[27] Schwartz, S.H., Cieciuch, J., Vecchione, M., Davidov, E., Fischer, R., Beierlein, C., Ramos, A., Verkasalo, M., Lönnqvist, J.-E., Demirutku, K., Dirilen-Gumus, O. \& Konty, M. Refining the Theory of Basic Individual Values, Journal of Personality and Social Psychology, 103(4), 2012, pp. 663-688.

[28] Adell, F.L., Castillo, I., Álvarez, O. \&Tomás, I. Personal values in youth basketball and its relationship with well-being and future intention to practice through motivation, Cuadernos de Psicologia del Deporte, 19, Issue 2, 2019, pp. 227242.

[29] Wayment, H.A. \& Bauer, J.J. The Quiet Ego: Motives for Self-Other Balance and Growth in Relation to Well-Being, Journal of Happiness Studies, Vol. 19, Issue 3, 2018, pp. 881-896.

[30] Tang, N., Wang, Y. \& Zhang, K. Values of Chinese generation cohorts: Do they matter in the workplace?, Organizational Behavior and Human Decision Processes, Vol. 143, 2017, pp. 8-22.

[31] Fedotova, V.A. Individual values as predictors of positive or negative attitudes towards innovation among representatives of various generations of Russian people, Psychology, Journal of the Higher School of Economics, Vol.14, Issue 4, 2017, pp. 717734.

[32] Tartakovsky, E.\& Walsh, S.D. Burnout among social workers working with immigrants from the Former Soviet Union and Ethiopia in Israel: Testing the connections between personal value preferences, immigrant appraisal and burnout, International Journal of Intercultural Relations, Vol. 53, 2016, pp. 39-53.

[33] Lilleoja, L.\& Saris, W.E. Does correction for measurement error have an effect on the structure and comparability of basic human values?, Survey Research Methods, Vol. 9, Issue 3, 2015, pp. 169187.

[34] Cieciuch, J., Schwartz, S.H. \& Vecchione, M. Applying the Refined Values Theory to Past Data: What Can Researchers Gain?, Journal of CrossCultural Psychology, Vol. 44, Issue 8, 2013, pp. 1215-1234.

[35] Barlińska, J. \& Szarota, P. Światopogląd a style randkowania, Psychologia Społeczna, T. 9, 4 (31), 2014, pp. 437-444.

[36] Biełous, E. \&Trzebiński, J. Nadzieja podstawowa a wizje świata społecznego, Psychologia Społeczna, T. 9, 4 (31), 2014, pp. 409421.

[37] Borowiak, A. \& Szarota, P. Światopogląd partnerów jako modulator miłości, Studia Psychologiczne, T. 42, 2004, pp. 15-26.

[38] Borowiak, A. \& Szarota, P. Światopogląd tradycjonalistyczny, modernistyczny i postmodernistyczny a współczesny dyskurs na temat tolerancji, In: Tolerancja i jej granice $w$ relacjach międzykulturowych, A. Posern-Zieliński (ed.), Wydawnictwo Poznańskie, Poznań 2004, pp. 117130. 
[39] Golec de Zavala, A. \& Van Bergh, A. Need for Cognitive Closure and Conservative Political Beliefs: Differential Mediation by Personal Worldviews, Political Psychology, 28(5), 2007, pp. 587-608.

[40] Bauman, Z. Socjologia, Zysk i S-ka, Poznań 1996.

[41] Bauman, Z. Etyka ponowoczesna, Wydawnictwo Naukowe PWN, Warszawa 1996.

[42] Bauman, Z. Śmierć i nieśmiertelność w ponowoczesnym świecie, In: Humanistyka przełomu wieków, J. Kozielecki (ed.), Wydawnictwo Akademickie Żak, Warszawa 1999, pp. 55-78.

[43] Gellner, E. Postmodernizm, rozum i religia, Wydawnictwo PIW, Warszawa 1997.

[44] Lyotard, J.F. Kondycja ponowoczesna. Raport o stanie wiedzy, Fundacja Aletheia, Warszawa 1997.

[45] Kiereś, H. Kultura klasyczna wobec postmodernizmu, Człowiek w Kulturze, 1998.

[46] Hejnicka-Bezwińska, T. Pedagogika ogólna, Wydawnictwo Akademickie i Profesjonalne, Warszawa 2008.

[47] Cieciuch, J. Pomiar wartości w zmodyfikowanym modelu Shaloma Schwartza, Psychologia Społeczna, T. 8 1(24), 2013, pp. 2241.

[48] Czerniawska, M. Zmiany wartości i postaw młodzieży $w$ okresie przeobrażeń ustrojowych. Kolektywizm versus indywidualizm. Studium interdyscyplinarne, Oficyna wydawnicza Politechniki Białostockiej, Białystok 2010.

[49] Cieciuch, J.\& Zaleski Z. Polska adaptacja Portretowego Kwestionariusz Wartości Shaloma Schwartza, Czasopismo Psychologiczne, T.17, No. 2, 2011, pp. 251-262.

[50] Schwartz, S.H. Individualism-collectivism. Critique and proposed refinements, Journal of CrossCultural Psychology, 21(2), 1990, pp. 139-157.

[51] Schwartz, S.H. \& Bilsky, W. Toward a theory of the universal content and structure of values: Extensions and cross-cultural replications, Journal of Personality and Social Psychology, 58(5), 1990, pp. 878-891.

[52] Czerniawska, М. Динамика ментальности в трансформирующихся обществах, Известия Российского Государственного Университета имени А.И. Гериена, 9 (47), 2007, pp. 133-148.

[53] Czerniawska, M. Co i dlaczego cenimy? czynniki warunkujące preferencje wartości, Kwartalnik Pedagogiczny, 3 (217), 2010, pp. 41-60.

[54] Czerniawska, M. Teorie wartości Miltona Rokeacha i Shaloma H. Schwartza, Kwartalnik Pedagogiczny, 4 (218), 2010, pp. 5-18.
[55] Czerniawska, M. O wartościach i ich zmianie raport z badań porównawczych nad systemami wartości studentów, Kultura i Edukacja, 3(113), 2016, pp. 135-153.

[56] Czerniawska, M. „Wolność” i „,równość”, ... a może „zbawienie”? - wartości determinujące postawy wobec ustroju ekonomicznego i kwestii socjalnych, Prakseologia, 160, 2018, pp. 19-40.

[57] Szydło, J. Kulturowe ramy zarzadzania, Wydawnictwo Naukowe Sophia, Katowice 2018.

[58] Szydło, J. \& Grześ-Bukłaho J. Relations between National and Organisational Culture-Case Study, Sustainability, Vol. 12, No. 4, 2020.

[59] Rybaczuk, M., Nazarko, J. \& Czerniawska, M. Graficzna prezentacja struktury empirycznych danych wielowymiarowych: opis i zastosowanie metody, Przeglad Psychologiczny, T. 50, No. 3, 2007, pp. 329-334.

[60] Triandis, H.C. \& Gelfand, M.J. Converging measurement of horizontal and vertical individualism and collectivism, Journal of Personality and Social Psychology, T. 74(1), 1998, pp. 118-128.

[61] Schwartz, S.H. Universals in the Content and Structure of Values: Theoretical Advances and Empirical Tests in 20 Countries, Advances in Experimental Social Psychology, 25, 1992, pp. 1-65. [62] Schwartz, S. H. Value orientations: Measurement, antecedents and consequences across nations. In: Measuring attitudes cross-nationally lessons from the European Social Survey, R. Jowell, C. Roberts, R. Fitzgerald, \& G. Eva (ed.), Sage, London 2006, pp. 169-203.

[63] Golec de Zavala, A. \& Van Bergh, A. Need for Cognitive Closure and Conservative Political Beliefs: Differential Mediation by Personal Worldviews, Political Psychology, 28(5), pp. 587608.

[64] Rohan, M.J. A rose by any name? The values construct, Personality and Social Psychology Review, 4(3), 2000, pp. 255-277.

[65] Maslach, C., Stapp, J. \& Santee, R.T. Individuation: Conceptual analysis and assessment, Journal of Personality and Social Psychology, 49, 1985, pp. 729-739.

[66] Reykowski, J. Kolektywizm i indywidualizm jako kategorie opisu zmian społecznych i mentalności, Przegląd Psychologiczny, 35, 1992, pp. 147-171.

[67] Jarymowicz, M. O formach umysłowego ujmowania My i ich związku ze spostrzeganiem Innych. In: Poza egocentryczna perspektywa widzenia siebie $i$ świata, M. Jarymowicz (ed.), 
Wydawnictwo Instytutu Psychologii PAN, Warszawa 1994, pp. 191-199.

[68] Skarżyńska, K. Człowiek a polityka. Zarys psychologii politycznej, Wydawnictwo Naukowe Scholar, Warszawa 2005.

[69] Schwartz, S.H. Mapping and interpreting cultural differences around the world. In: Comparing culture, dimensions of culture in comparative perspective, H. Vinken, J. Soeters \& P. Ester (ed.), Brill, Leiden 2003, pp. 43-73.

\section{Creative Commons Attribution}

\section{License 4.0 (Attribution 4.0}

International , CC BY 4.0)

This article is published under the terms of the Creative Commons Attribution License 4.0

https://creativecommons.org/licenses/by/4.0/deed.en $\underline{\text { US }}$ 